\title{
PERILAKU ORGANISASIONAL PADA IMPLEMENTASI SISTEM INFORMASI KEUANGAN DAERAH (SIKD) (Studi Empiris Pada Pemerintah Daerah Kabupaten Sragen)
}

\author{
Supartini \\ Universitas Tunas Bangsa Surakarta \\ e-mail: tini_fe@yahoo.com
}

\begin{abstract}
ABSTRAK
Local Financial Information System (SIKD) can give the better information for the decision making of strategic specially relate to the transparency and accountability in public sector. This research aim to test the relation between SKID implementation factor that supported, clarity of target, training with the cognitive conflict, affective conflict, the usefulness of SIKD, then cognitive and affective conflict by usefulness of SIKD and also the relation of SIKD's usefulness by cost consciousness. Data obtained by propagating questioner to head on duty, chief, the institution's leader, the area's leader, superintendent, secretary of area and secretary DPRD of local government of Sragen Regency. The result of this research supports Chenhall (2004) which indicates the usefulness of ABCM for the scheme of product related to the financial succeed. This research suggests that in the system implementation, pays attention to other factors and requires to be developed to check the technical factors.

Keywords: Head on duty's support, clarity of target trainning, cognitive conflict, affective conflict, usefulness of SIKD, cost consciousness.
\end{abstract}

\section{PENDAHULUAN}

Pada masa pemerintahan sentralistik (orde baru), Sistem Informasi Keuangan Daerah yang disingkat SIKD di seluruh Indonesia diatur dalam Undang-Undang (UU) nomor 5 tahun 1974, dilengkapi dengan Peraturan Pemerintah (PP) nomor 5 tahun 1975 dan Peraturan Pemerintah(PP) nomor 6 tahun 1975. Dalam SIKD tersentralisasi, pengguna SIKD adalah terutama Kepala Daerah sebab hampir semua keputusan penganggaran yang berbasis SIKD adalah keputusan Kepala Daerah. Model SIKD terdesentralisasi, pengguna SIKD tidak hanya Kepala Daerah, bahkan memungkinkan dan mengharuskan para manajer pemerintah (perangkat) daerah (Kepala Badan, Kepala Kantor, Kepala Dinas dan unit lainnya). Sesuai UU No. 33 tahun 2004, pasal 72 dinyatakan bahwa Satuan Kerja Perangkat Daerah (SKPD), bisa Badan, Dinas, Kantor dan unit lainnya, harus menyusun rencana Kerja dan Anggaran SKPD yang kemudian disebut RKA SKPD.

Perubahan sistem pemerintahan sentralistik menuju pemerintahan desentralistik (Otonomi Daerah) telah menyebabkan perubahan tuntutan dan kebutuhan. Salah satunya adalah tuntutan dan kebutuhan akan SIKD yang memadai. Nilai SIKD sangat ditentukan oleh persepsi dan kepercayaan pengguna akan informasi tersebut. Informasi tentang organisasi pemerintahan khususnya 
SIKD hanya dapat diterima umum jika SIKD digunakan sebagai media untuk menciptakan pemerintahan daerah yang bersih, benar dan transparan. Informasi keuangan daerah yang disampaikan harus memenuhi prinsip-prinsip akurat, relevan dan dapat dipertanggungjawabkan. Oleh karena itu diperlukan sistem pengelolaan keuangan daerah yang baik dalam rangka mengelola dana secara transparan, ekonomis, efisien, efektif dan akuntabel (Indra, 2001).

Sebagai pelaksanaan Undang-Undang Nomor 33 Tahun 2004 tentang Perimbangan Keuangan antara Pemerintah Pusat dan Pemerintah Daerah mengamanatkan adanya dukungan SIKD untuk menunjang perumusan kebijakan fiskal secara nasional serta meningkatkan transparasi dan akuntabilitas dalam pelaksanaan desentralisasi. Namun, berbagai implikasi harus pula dipahami, seperti perilaku aparatur pemerintah daerah dan anggota Dewan Perwakilan Rakyat Daerah (DPRD) dalam pembuatan kebijakan publik (Abdul, 2004).

Penelitian ini akan membahas tentang faktor perilaku organisasional, peran konflik dalam implementasi SIKD pada Pemerintah Daerah (Pemda) yang melakukan implementasi SIKD. Chenhall, (2004) menjelaskan adanya hubungan positif antara keberhasilan implementasi suatu sistem dengan perhatian yang diberikan pada faktor perilaku selama proses implementasi. Hubungan tersebut terjadi karena adanya intervensi dari konflik kognitif dan konflik afektif yang terjadi selama proses implementasi.

Penelitian ini memfokuskan pada tiga faktor implementasi SIKD, yaitu dukungan atasan, kejelasan tujuan dan pelatihan. Secara empiris hal ini relevan dengan penelitian Chenhall, (2004) tentang keberhasilan implementasi $A B C M$ yang memfokus pada tiga faktor implementasi yaitu dukungan atasan, kejelasan tujuan dan pelatihan.
Penelitian ini akan menguji faktor implementasi perilaku organisasional dan peran konflik baik konflik kognitif maupun konflik afektif terhadap implementasi SIKD dan apakah impelementasi SIKD meningkatkan penggunaan sistem (SIKD) dan kinerja aparat pemerintah di Kabupaten Sragen. Kabupaten Sragen saat ini sebagai Kabupaten percotohan di bidang inovasi dan pada taggal 31 Agustus 2006 Kabupaten Sragen mendapat Aword dari Presiden Republik Indonesia. Kabupaten Sragen memiliki karakteristik dalam implementasi SIKD yang sesuai dengan tujuan penelitian.

\section{Rumusan Masalah}

Implementasi SIKD merupakan salah satu bentuk pengendalian yang digunakan untuk pencapaian kinerja. Penelitian yang dilakukan oleh Arbenethy dan Jan Bouwens (2005) mengemukakan bahwa implementasi inovasi sistem akuntansi manajamen mempengaruhi kepuasan dan kinerja pegawai.

Menurut Indra (2002) implementasi SIKD ditujukan dalam rangka mengelola dana secara transaparan, efisien, efektif dan akuntabel. Implementasi SIKD diharapkan mampu meningkatkan penggunaan sistem dan diharapkan dapat meningkatkan kinerja aparat pemerintah daerah dalam rangka memenuhi tuntutan masyarakat tentang transaparansi dan akuntanbilitas dari lembaga sektor publik.

Penelitian ini akan menguji faktor-faktor implementasi SIKD, peran konflik kognitif dan konflik afektif pada implementasi SIKD untuk meningkatkan kegunaan SIKD, dan diharapkan dapat meningkatkan kinerja aparat pemerintah daerah yang dalam penelitian ini disebut cost consciousness. Faktor-faktor implementasi SIKD dalam penelitian ini yaitu dukungan atasan pemerintah daerah, kejelasan tujuan dan pelatihan. Sesuai latar belakang penelitian, rumusan masalah adalah sebagai berikut: 
1. Apakah dukungan atasan, kejelasan tujuan dan pelatihan akan meningkatkan konflik kognitif?

2. Apakah dukungan atasan, kejelasan tujuan dan pelatihan akan menurunkan konflik afektif?

3. Apakah dukungan atasan, kejelasan tujuan dan pelatihan akan meningkatkan kegunaan SIKD?

4. Apakah konflik kognitif dan konflik afektif akan meningkatkan kegunaan SIKD?

5. Apakah kegunaan SIKD akan meningkatkan cost consciousness?

Hasil penelitian ini diharapkan dapat memberikan kontribusi bagi pengembangan akuntansi keperilakuan, khususnya faktor-faktor organisasional, peran konflik kognitif dan konflik afektif pada implementasi SIKD. Temuan penelitian ini diharapkan juga dapat ditindaklanjuti oleh peneliti seterusnya dan memberikan masukan pada aplikasi praktis bagi pemerintah daerah, terkait dengan implementasi sistem baru dan pentingnya kegunaan sistem tersebut serta cost consciousness.

\section{REVIEW LITERATUR DAN HIPOTESIS}

\section{Theory of Reasoned Action (TRA)}

Penelitian ini bertujuan untuk mendeskripsikan hubungan antara sikap dan perilaku individu dengan implementasi SIKD. Dalam Theory of Reasoned Action (TRA) yang dikemukakan oleh Fishbein dan Ajzen (1975) dalam Ahmad (2004) yaitu suatu teori yang berhubungan dengan sikap dan perilaku individu dalam melaksanakan kegiatan/tindakan yang beralasan (reasoned action). Teori ini mengungkapkan dalam konteks penggunaan teknologi informasi, bahwa seseorang akan menggunakan teknologi informasi jika dia dapat melihat adanya manfaat positif dari penggunanaan teknologi informasi tersebut.
Menurut Peraturan Pemerintah Nomor 56 tahun 2005 tentang SIKD, Pemerintah dan Pemerintah Daerah berkewajiban untuk mengembangkan dan memanfaatkan kemajuan teknologi informasi untuk meningkatkan kemampuan mengelola keuangan daerah, dan menyalurkan Informasi Keuangan Daerah kepada pelayanan publik. Pemerintah perlu mengoptimasikan pemanfaatan kemajuan teknologi informasi untuk membangun jaringan sistem informasi manajemen dan proses kerja yang memungkinkan pemerintah bekerja secara terpadu dengan menyederhanakan akses unit kerja.

Terdapat dua hal yang memiliki korelasi kuat dan konsisten dengan diterimanya implementasi sebuah sistem pemanfaatan teknologi informasi yaitu kepuasan pengguna dan kinerja pada tingkat kompetensi sistem tersebut (Mawhinney, 1990) dalam Ahmad (2004). Definisi tersebut dapat diartikan bahwa pemanfaatan dari penggunaan sistem informasi dapat meningkatkan kepuasan dan kinerja pihak yang menggunakannya. Berdasarkan definisi tersebut apabila dikaitkan dengan implementasi SIKD maka dapat dikatakan dengan diterimanya implementasi SIKD diharapkan dapat meningkatkan kegunaan sistem dan kinerja aparat pemda.

\section{Faktor-faktor Implementasi SIKD dan konflik}

Faktor-faktor implementasi SIKD dianggap sebagai cara paling efektif untuk meyakinkan keberhasilan aplikasi dari $A B C M$, sebagai salah satu bagian implementasi secara keseluruhan (Shields, 1995). Penelitian Chenhall (2004) tiga dimensi dari implementasi perilaku yaitu dukungan atasan, kejelasan tujuan, dan pelatihan. Pada penelitia ini, faktor perilaku berkaitan degan implementasi SIKD sama dengan yang digunakan Chenhall (2004) yaitu dukungan atasan, kejelasan tujuan, dan pelatihan. 
Dukungan atasan merupakan dukungan dari atasan (Pemda) untuk memberikan sumber daya yang diperlukan dalam implementasi SIKD, dan hubungannya dengan kemajuan dan efisiensi. Kejelasan tujuan diartikan ketika akan menerapkan SIKD, tujuan implementasi SIKD tersebut telah dijelaskan dan disepakati. Kejelasan tujuan dapat mendorong tercapainya suatu komitmen. Pelatihan yang berkaitan dengan implementasi, desain dan penggunaan SIKD dapat memberikan mekanisme bagi pengguna untuk memahami dan menerima dasar dari SIKD.

Dalam penelitian ini akan menguji hubungan antara faktor-faktor implementasi SIKD dengan konflik kognitif dan konflik afektif. Sehingga dikembangkan hipotesis sebagai berikut.

H1a : Dukungan atasan berhubungan positif dengan konflik kognitif.

$\mathrm{H} 1 \mathrm{~b}$ : Kejelasan tujuan berhubungan positif dengan konflik kognitif.

H1c : Pelatihan berhubungan positif dengan konflik kognitif.

$\mathrm{H} 2 \mathrm{a}$ : Dukungan atasan berhubungan negatif dengan konflik afektif

$\mathrm{H} 2 \mathrm{~b}$ : Kejelasan tujuan berhubungan negatif dengan konflik afektif

$\mathrm{H} 2 \mathrm{c}$ : Pelatihan berhubungan negatif dengan konflik afektif

\section{Faktor-faktor implementasi SIKD dan Kegunaan SIKD}

Menurut PPRI No. 56 Tahun 2005 bab II pasal 1 ayat 15, SIKD adalah suatu sistem yang men-dokumentasikan, mengadminitrasikan, serta mengolah data pengelolaan keuangan daerah dan data terkait lainnya menjadi informasi yang disajikan kepada masyarakat dan sebagai bahan pengambilan keputusan dalam rangka perencanaan, pelaksanaan, dan pelaporan pertanggungjawaban pemerintah daerah. SIKD dipandang sebagai peningkatan dari sistem sentralisasi ke sistem desentralisasi. Menurut Arbenethy (2005) desentralisasi merupakan pemberian wewenang dan otoritas kepada manajer sub unit untuk mengambil suatu tindakan yang akan mempengaruhi kemampuan adaptasi dari pihak manajer sub unit.

Faktor-faktor implementasi berhubungan dengan implementasi SIKD yang berhasil meliputi dukungan dari atasan, kejelasan tujuan dan pelatihan. Dukungan atasan kaitannya dengan kemajuan dan efisiensi, penyediaan sumber daya yang dibutuhkan untuk implementasi SIKD. Kejelasan tujuan memberikan gambaran tentang ketika akan mengimplementasikan SIKD tujuan implementasi sistem tersebut harus jelas dan ringkas, dan telah ada persetujuan tentang tujuan implementasi SIKD, serta SIKD bermanfaat untuk semua bagian dalam departemen/dinas. Pelatihan menjelaskan pelatihan yang disediakan bagi para pegawai berkaitan dengan implementasi SIKD, keterkaitan SIKD, kegunaan SIKD sehingga meningkatkan pemahaman sistem.

Berdasarkan argumen di atas dapat dijadikan dasar untuk membangun hipotesis sebagai berikut:

H3a : Dukungan atasan berhubungan positif dengan kegunaan SIKD

$\mathrm{H} 3 \mathrm{~b}$ : Kejelasan tujuan berhubungan positif dengan kegunaan SIKD

$\mathrm{H} 3 \mathrm{c}$ : Pelatihan berhubungan positif dengan kegunaan SIKD

\section{Konflik. Kognitif dan Kegunaan Sistem Informasi Keuangan Daerah (SIKD).}

Konflik kognitif merupakan konflik mengenai sesuatu seperti pandangan, ide, strategi, prosedur, kebijakan, opini dan sumber daya. Konflik kognitif dapat bermanfaat untuk memecahkan masalah dan mendorong ke arah perbaikan dari pendapat yang berlawanan dalam pengambilan keputusan. 
Chenhall (2004) telah meneliti konflik kognitif dalam implementasi tahap awal $A B C M$ dengan kesimpulan ada hubungan positif antara konflik kognitif dengan kegunaan $A B C M$. Sementara Lina (2005) tidak berhasil membuktikan konflik kognitif berhubungan positif dengan kegunaan SAKD. Oleh karena itu dikembangkan hipotesis sebagai berikut.

H4 : Konflik kognitif berhubungan positif dengan kegunaan SIKD

\section{Konflik Afektif dan Kegunaan Sistem Informasi Keuangan Daerah (SIKD)}

Konflik afektif cenderung melibatkan persepsi yang mengancam posisi seseorang di dalam suatu kelompok, pertikaian, frustasi dan aksi antara pribadi sesorang dengan nilai norma yang ada. Pada saat manager memperkenalkan suatu sistem baru kepada anggota organisasi, ada kemungkinan beberapa anggota tidak setuju diterapkannya sistem baru tersebut. SIKD berpotensi untuk berkembang menuju tahapan dimana sistem ini akan diterima karena memberikan infromasi yang berguna untuk pengambilan keputusan strategis yang lebih baik berkaitan dengan transparansi dan akuntabilitas di sektor publik.

Berkaitan dengan implementasi $A B C M$ dalam penelitian Chenhall (2004), konflik afektif berpotensi dapat mengurangi kegunaan $A B C M$ untuk perencaaan produk dan manajemen pembiayaan. Konflik afektif dalam implementasi SIKD kemungkinan akan menghambat keberhasilan implementasi SIKD. Hipotesis yang dikembangkan dalam penelitian ini sebagai berikut.

H5 : Konflik afektif berhubungan negatif dengan kegunaan SIKD

\section{Kegunaan SIKD dan Cost Consciousness}

Menurut Chenhall (2004) keberadaan $A B C M$ dapat memberikan informasi yang berguna untuk perencanaan produk dan manajemen pembiayaan, sehingga akan terjadi beberapa peningkatan dalam kinerja keuangan. Dalam penelitian ini keberadaan SIKD memberikan informasi yang berguna untuk transparansi dan akuntabilitas di sektor publik, sehingga diharapkan mempunyai dampak kepedulian aparatur pemerintahan daerah terhadap efeisiensi dan keefektifan biaya yang dalam penelitian ini disebut Cost Conciousness.

Dalam penelitian ini, efisiensi dan keefektifan perilaku aparatur pemerintahan daerah sebagaimana dinyatakan di atas diadopsi, diukur dan diproksi dengan menggunakan dan mendasarkan pada konsep Cost Conciousness yang dikembangkan oleh Young dan Shield (1994) dalam Chairina (2005). Inti dari konsep ini adalah bagaimana aparat pemerintahan daerah menaruh perhatian secara serius terhadap konsekwensi cost yang timbul bila sebuah keputusan telah diambil dan ditetapkan oleh aparatur pemerintahan daerah tersebut. Hipotesis dapat dinyatakan sebagai berikut.

H6 : Kegunaan SIKD berhubungan positif dengan Cost consiousnes.

\section{METODE PENELITIAN}

Populasi Penelitian ini adalah Kepala Dinas, Kepala Badan, Kepala Kantor, Kepala Bagian, Kepala Bidang, Sekretariat Daerah dan Sekretariat DPRD di pemerintah daerah Kabupaten Sragen. Kabupaten Sragen saat ini sebagai Kabupaten percontohan dan pada tanggal 31 Agustus 2006 Kabupaten Sragen mendapat Aword dari Presiden Republik Indonesia di bidang inovasi.

\section{Definisi Operasional Variabel}

Dalam penelitian ini variabel-variabel terdiri dari variabel eksogen dan variabel endogen. Variabel eksogen adalah faktor-faktor yang mempengaruhi implementasi SIKD, yang terdiri dari dukungan atasan, kejelasan tujuan, dan 
pelatihan. Variabel endogennya adalah konflik kognitif, konflik afektif, kegunaan SIKD serta Cost Consciousness.

1. Dukungan atasan diartikan sebagai dukungan atau keterlibatan manajer dalam kemajuan proyek dan keterlibatan manajer dalam menyediakan sumber daya yang diperlukan sesuai kebutuhan.

2. Kejelasan tujuan diartikan sebagai kejelasan diterapkan dan digunakannya SIKD.

3. Pelatihan adalah pelatihan yang disediakan bagi pegawai yang berkaitan dengan implementasi SIKD. Pelatihan memberikan dasar untuk meningkatkan pemahaman tentang SIKD.

4. Konflik kognitif adalah konflik yang memiliki dampak yang menguntungkan dapat meningkatkan kualitas keputusan yang diambil.

5. Konflik Afektif adalah konflik yang disfungsional dan dapat mengancam kualitas dari keputusan tersebut karena konflik akan melemahkan kemampuan individu untuk bekerja sama

6. Kegunaan SIKD diartikan bahwa SIKD dapat memberikan informasi yang lebih baik untuk pengambilan keputusan strategis khususnya berkaitan dengan transparasi dan akuntabilitas di sektor publik. SIKD hanya dapat diterima umum jika SIKD sebagai media untuk menciptakan pemerintahan daerah yang bersih, benar dan transparan.

7. Cost Consciousness merupakan kondisi dimana manajer sangat menyadari tentang arti penting biaya dan waktu yang dibutuhkan dalam setiap pengambilan keputusan

\section{HASIL PENELITIAN DAN PEMBAHASAN}

Responden dalam penelitian ini sebanyak 110 orang di pemerintah daerah Kabupaten Sragen. Terdiri dari kepala dinas 12 orang, kepala badan
5 orang, kepala kantor 5 orang, kepala bidang 56 orang, kepala bagian 21 orang, sekretariat daerah 10 orang dan sekretariat DPRD 4 orang.

Untuk menguji hipotesis dalam penelitian ini menggunakan alat statistik yaitu teknik Multivariate Struktur Equation Model (SEM) dengan menggunakan software LISREL 8.54.

\section{Uji kualitas Data}

Uji kualitas data meliputi uji reliabilitas dan uji validitas. Uji reliabilitas dilakukan dengan uji cronbach alpha menggunakan SPSS. Suatu kontruk dikatakan reliabel jika memberikan nilai cronbach alpha > 0,60 ( Nunanaly, 1967 dalam Imam, 2005). Hasil uji reliabilitas disajikan pada tabel 1 di bawah ini:

\section{Tabel 1}

Hasil Uji reliabilitas

\begin{tabular}{cccc}
\hline No & Variabel & $\begin{array}{c}\text { Nilai } \\
\text { Cronbach } \\
\text { Alpha }\end{array}$ & Keterangan \\
\hline 1 & Dukungan Atasan & 0,85 & Reliabel \\
2 & Kejelasan Tujuan & 0,89 & Reliabel \\
3 & Pelatihan & 0,94 & Reliabel \\
4 & Konflik Kognitif & 0,86 & Reliabel \\
5 & Konflik Afektif & 0,94 & Reliabel \\
6 & Penggunaan SIKD & 0,90 & Reliabel \\
7 & Cost Consciousness & 0,77 & Reliabel \\
\hline
\end{tabular}

Sumber : Hasil Pengujian Reliabilitas

Tabel di atas menunjukkan bahwa variabel dukungan atasan mempunyai nilai cronbach alpha 0,85 . Variabel kejelasan tujuan mempunyai nilai cronbach alpha 0,89 . Variabel pelatihan mempunyai nilai cronbach alpha 0,94 . Variabel konflik kognitif, variabel konflik afektif, variabel penggunaan SIKD dan variabel cost Consciousness masing-masing mempunyai nilai cronbach alpha 0,$86 ; 0,94 ; 0,90$ dan 0,77 . Semua nilai tersebut di atas 0,6 . Maka semua pertanyaan-pertanyaan dari variabel dukungan atasan, kejelasan tujuan, pelatihan, konflik kognitif, konflik afektif, penggunaan SIKD dan cost Consciousness mempunyai adalah reliabel. 
Uji validitas dilakukan dengan melakukan korelasi bivariate (pearson correlation) antara masing-masing skor indikator dengan skor kontruk. Suatu indikator pertanyaan dikatakan valid apabila korelasi antara masing-masing indikator menunjukkan hasil yang signifikan. Hasil dari uji validitas dapat dilihat pada tabel berikut ini :

Tabel 2

Hasil Uji Validitas

\begin{tabular}{ccccc}
\hline No & Variabel & Kisaran Korelasi & $\begin{array}{c}\text { Signifi- } \\
\text { kansi }\end{array}$ & $\begin{array}{c}\text { Ketera- } \\
\text { ngan }\end{array}$ \\
\hline 1 & $\begin{array}{c}\text { Dukungan } \\
\text { Atasan } \\
\text { Kejelasan } \\
\text { Tujuan }\end{array}$ & $0,710^{* *-0,844 * *}$ & 0,01 & Valid \\
2 & $0,786 * *-0,891 * *$ & 0,01 & Valid \\
3 & $\begin{array}{c}\text { Pelatihan } \\
\text { Konflik }\end{array}$ & $0,884 * *-0,948 * *$ & 0,01 & Valid \\
4 & $\begin{array}{c}\text { Kognitif } \\
\text { Konflik }\end{array}$ & $0,800 * *-0,879 * *$ & 0,01 & Valid \\
5 & $\begin{array}{c}\text { Afektif } \\
\text { kegunaan } \\
\text { SIKD }\end{array}$ & $0,821 * *-0,897 *$ & 0,01 & Valid \\
7 & $\begin{array}{c}\text { Cost Cons- } \\
\text { ciousness }\end{array}$ & $0,570 * *-0,782 * *$ & 0,01 & Valid \\
\hline
\end{tabular}

** : Signifikan. Sumber : Hasil Pengujian Validitas

Berdasarkan di atas variabel dukungan atasan mempunyai kisaran korelasi antara 0,710 sampai dengan 0,844 dan signifikan pada tingkat 0,01 menunjukkan bahwa pertanyaan-pertanyaan tentang dukungan atasan dikatakan valid. Demikian juga variabel kejelasan tujuan berada pada kisaran korelasi 0,786 samapai 0,891 pada tingkat signifikan 0,01 mengindikasikan masing-masing pertanyaan indikator sudah valid. Variabel pelatihan mempunyai kisaram korelasi antara 0,884 sampai dengan 0,948 dan signifikan pada tingkat 0,01 menunjukkan bahwa pertanyaan-pertanyaan yang mengukur pelatihan dikatakan valid.

Untuk variabel konflik kognitif dan konflik afektif masing-masing mempunyai kisaran teoritis 0,800 sampai 0,879 dan 0,821 sampai 0,897 dan signifikan pada tingkat 0,01 mengindikasikan masing-masing pertanyaan indikator sudah valid. Sedang variabel kegunaan SIKD dan cost cons- ciousness mempunyai kisaran teoritis masingmasing 0,754 sampai 0,925 dan 0,570 sampai 0,782 dan signifikan pada tingkat 0,01 menunjukkan bahwa pertanyaan-pertanyaan pada variabel tersebut adalah valid.

Dari hasil tersebut dapat disimpulkan bahwa pertanyaan-pertanyaan yang mengukur konstruk dukungan atasan, kejelasan tujuan, pelatihan, konflik kognitif, konflik afektif, kegunaan SIKD dan cost consciousness adalah valid artinya benar-benar mengungkapkan hal yang diukur dalam kuesioner.

\section{Pengujian Hipotesis}

Analisis full model structural equation model dengan program LISREL 8.54 digunakan untuk menganalisis hubungan antara variabel-variabel laten. Menguji kesesuaian model yang dievaluasi dengan criteria goodness of fit. Hasil pengujian kesesuaian model menunjukkan goodness offit indeces yang baik. Hal ini mengindikasikan bahwa secara statistic maupun secara teori model yang dibangun secara baik menjelaskan dan mendefinisikan variabel penelitian. Goodness of fit dari model penelitian ditunjukkan dalam tabel 3 .

Tabel 3

Goodness Of Fit Indices Full Model

\begin{tabular}{cccc}
\hline $\begin{array}{c}\text { Goodness- } \\
\text { of-fit Indices }\end{array}$ & Cut-off Value & $\begin{array}{c}\text { Hasil } \\
\text { Model }\end{array}$ & Keterangan \\
\hline Chi-Square & $\geq 0,05$ & 4,102 & Fit \\
Probability & $>0,05$ & 0,546 & Fit \\
NFI & $>0,90$ & 0,99 & Fit \\
NNFI & $>0,90$ & 1,01 & Perfect Fit \\
CFI & $>0,90$ & 1,00 & Perfect Fit \\
IFI & $>0,90$ & 1,00 & Perfect Fit \\
RFI & $>0,90$ & 0,94 & Fit \\
\hline
\end{tabular}

Sumber : Hasil Pengujian Goodness of Fit Model Output Lisrel 8.54 
Untuk menguji hipotesis dilakukan dengan melihat nilai regression weight pada kolom $C R$ (Critikal Ratio) yang dihasilkan dengan program LISREL 8.54. Nilai CR dibandingkan dengan nilai kritisnya 1,66 pada signifikansi $5 \%$. Jika nilai CR hasil pengolahan data (LISREL) telah melampoi nilai kritisnya ( $\mathrm{t}$ tabel) dengan tingkat signifikansi $\mathrm{P}<0,05$ maka hipotesis alternatif yang diajukan diterima. Hasil regression weight model penelitian ini dijelaskan dalam tabel 4 .

\section{Tabel 4}

\section{Regression Weight Model Struktural}

\begin{tabular}{lcccc}
\hline & $\begin{array}{c}\text { STANDAR- } \\
\text { DIZED } \\
\text { ESTIMATE }\end{array}$ & SE & t-Value & KEPUTUSAN \\
\hline $\mathrm{KK} \leftarrow \mathrm{DA}$ & 0,011 & 0,155 & 0,070 & Tidak Signifikan \\
$\mathrm{KK} \leftarrow \mathrm{KJ}$ & $-0,254$ & 0,145 & $-1,758$ & Tidak Signifikan \\
$\mathrm{KK} \leftarrow \mathrm{PL}$ & 0,355 & 0,0817 & 4,338 & Signifikan \\
$\mathrm{KA} \leftarrow \mathrm{DA}$ & $-0,148$ & 0,263 & $-0,564$ & Tidak Signifikan \\
$\mathrm{KA} \leftarrow \mathrm{KJ}$ & $-0,276$ & 0,246 & $-1,123$ & Tidak Signifikan \\
$\mathrm{KA} \leftarrow \mathrm{PL}$ & 0,618 & 0,139 & 4,444 & Signifikan \\
$\mathrm{GS} \leftarrow \mathrm{KK}$ & $-0,016$ & 0,087 & $-0,187$ & Tidak Signifikan \\
$\mathrm{GS} \leftarrow \mathrm{KA}$ & 0,032 & 0,051 & 0,620 & Tidak Signifikan \\
$\mathrm{GS} \leftarrow \mathrm{DA}$ & 0,161 & 0,104 & 1,553 & Tidak Signifikan \\
$\mathrm{GS} \leftarrow \mathrm{KJ}$ & 0,384 & 0,098 & 3,918 & Signifikan \\
$\mathrm{GS} \leftarrow \mathrm{PL}$ & 0,026 & 0,061 & 0,430 & Tidak Signifikan \\
$\mathrm{CC} \leftarrow \mathrm{GS}$ & 0,702 & 0,121 & 5,814 & Signifikan \\
\hline
\end{tabular}

Sumber : Hasil Pengujian Regression Weight Model Struktural

Keterangan : DA : Dukungan Atasan

KJ : Kejelasan Tujuan

PL : Pelatihan

KK : Konflik Kognitif

KA : Konflik Afektif

GS : Kegunaan SIKD

CC : Cost Consciousness

\section{Dukungan Atasan dengan Konflik Kognitif, Konflik Afektif dan Kegunaan SIKD}

Pengujian hipotesis 1a tidak mampu mendukung dugaan bahwa dukungan atasan berhubungan posistif dengan konflik kognitif. Hasil temuan ini konsisten dengan penelitian Chenhall (2004) yang menyatakan dukungan manajemen puncak tidak berhubungan secara signifikan dengan konflik kognitif. Penelitian ini juga mendukung penelitiannya Lina (2005) yang menyatakan dukungan atasan tidak berhubungan dengan konflik kognitif.

Pengujian hipotesis 2a tidak mendukung dugaan bahwa dukungan atasan berhubungan negatif dengan konflik afektif. Hasil temuan ini konsisten dengan penelitian Chenhall (2004) yang menyatakan dukungan manajemen puncak tidak berhubungan secara signifikan dengan konflik afektif. Penelitian ini juga mendukung penelitiannya Lina (2005) yang menyatakan dukungan atasan tidak berhubungan dengan konflik afektif.

Pengujian hipotesis 3a tidak mampu mendukung dugaan bahwa dukungan atasan berhubungan positif dengan kegunaan SIKD. Hasil penelitian ini tidak konsisten dengan penelitian Chenhall (2004) dan Lina (2005). Menurut Chenhall (2004) dukungan manajemen puncak memiliki pengaruh langsung secara marginal atas kegunaan $\mathrm{ABCM}$ untuk manajemen pembiayaan pada tingkat signifikansi 10\%. Begitu juga Lina (2005) menyatakan bahwa dukungan atasan berhubungan positif dengan kegunaan SAKD.

SIKD dapat memberikan informasi yang lebih baik untuk pengambilan keputusan strategis khususnya berkaitan dengan transparasi dan akuntabilitas di sektor publik. Suatu sistem baru (SIKD) akan diterima oleh anggota organisasi apabila ada legitimasi melalui dukungan atasan. Tampaknya sumber daya yang disediakan untuk implementsai sistem baru (SIKD) belum memiliki peranan dalam mendukung implementsai SIKD dan kurang potensial mempengaruhi munculnya konflik. Sehingga sumber daya yang disediakan juga kurang memberikan peranan terhadap kegunaan SIKD. 
Kejelasan Tujuan dengan Konflik Kognitif, Konflik Afektif dan Kegunaan SIKD

Pengujian hipotesis $1 \mathrm{~b}$ tidak mampu mendukung dugaan bahwa kejelasan tujuan berhubungan posistif dengan konflik kognitif. Hasil temuan ini tidak konsisten dengan penelitian Chenhall (2004) dan Lina (2005). Chenhall (2004) menyatakan bahwa kejelasan tujuan berhubungan positif dengan konflik kognitif. Lina (2005) menyatakan bahwa kejelasan tujuan berhubungan negatif dengan konflik kognitif.

Pengujian hipotesis $2 \mathrm{~b}$ tidak mampu mendukung dugaan bahwa kejelasan tujuan berhubungan negatif dengan konflik afektif. Hal ini konsisten dengan penelitiannya Chenhall (2004) tapi tidak konsisten dengan penelitiannya Lina (2005). Menurut Lina (2005) menyatakan bahwa kejelasan tujuan berhubungan negatif dengan konflik afektif.

Pengujian hipotesis $3 \mathrm{~b}$ tidak mampu mendukung dugaan bahwa kejelasan tujuan berhubungan posistif dengan kegunaan SIKD. Hasil ini tidak mendukung penelitian Chenhall (2004), bahwa terdapat hubungan positif antara kegunaan ABCM dalam perencaan produk dengan pelatihan pada tingkat signifikansi $5 \%$ dan terdapat hubungan positif antara kegunaan ABCM dalam manajemen pembiayaan dengan pelatihan pada tingkat signifikansi $10 \%$. Hasil ini juga tidak mendukung penelitiannya Lina (2005), bahwa kejelasan tujuan berhubungan negatif dengan kegunaan SAKD.

Kejelasan tujuan diartikan ketika akan mengimplementasikan SIKD, tujuan implementasi SIKD tersebut telah dijelaskan dan disepakati. Implementasi SIKD akan berhasil apabila tujuan dari implemetasi SIKD telah dijelaskan dan telah ada persetujuan tentang tujuan implementasi SIKD, serta SIKD bermanfaat untuk semua bagian dalam pemda tersebut.
Faktor kejelasan tujuan belum mendorong memunculkan konflik kognitif dimana manajer kemungkinan belum memiliki kemampuan dan pengetahuan akan operasional aplikasi SIKD dan belum terlibat dalam suatu interaksi yang memfokuskan pada tugas untuk mengimplementasikan SIKD secara efektif. Faktor implementasi kejelasan tujuan juga belum memiliki peranan penting dalam memberikan manfaat SIKD untuk transparansi dan akuntabilitas di sektor publik. Hal tersebut disebabkan karena pengguna belum memahami tujuan dari implementasi SIKD itu sendiri.

\section{Pelatihan dengan Konflik Kognitif, Konflik Afektif dan Kegunaan SIKD}

Pengujian hipotesis 1c mampu mendukung dugaan bahwa pelatihan berhubungan positif dengan konflik kognitif. Hal ini konsisten dengan penelitiannya Chenhall (2004) tapi tidak konsisten dengan penelitiannya Lina (2005). Menurut Lina (2005), bahwa pelatihan berhubungan negatif dengan konflik kognitif.

Pengujian hipotesis 2c mampu mendukung dugaan bahwa pelatihan berhubungan negatif dengan konflik afektif. Hal ini konsisten dengan penelitiannya Lina (2005) tapi tidak konsisten dengan penelitiannya Chenhall (2004). Menurut Chenhall (2004) pelatihan tidak berhubungan negatif dengan konflik afektif.

Pengujian hipotesis $3 \mathrm{c}$ tidak mampu mendukung dugaan bahwa pelatihan berhubungan positif dengan kegunaan SIKD. Hal ini tidak konsisten dengan penelitian Chenhall (2004), bahwa terdapat hubungan posistif antara kegunaan ABCM dalam perencanaan produk dengan pelatihan pada signifikansi $10 \%$. Penelitian ini juga tidak mendukung penelitian Lina (2005), bahwa pelatihan berhubungan negatif dengan kegunaan SAKD. 
Pelatihan berkaitan dengan implementasi, desain dan penggunaan SIKD dapat memberikan mekanisme bagi pengguna untuk memahami dan menerima dasar dari SIKD. Pelatihan memberikan peranan penting dalam meyakinkan bahwa individu sudah memiliki ketrampilan dan rasa percaya diri dalam perdebatan yang mempermasalahkan implementasi SIKD. Pelatihan memiliki peranan untuk meningkatkan konflik kognitif tetapi belum belum memberikan manfaat untuk transparansi dan akuntabilitas di sektor publik.

\section{Konflik Kognitif, Konflik Afektif dengan Kegunaan SIKD}

Pengujian hipotesis 4 dan tidak mampu mendukung dugaan bahwa konflik kognitif berhubungan positif dengan kegunaan SIKD. Konflik kognitif tidak berhubungan dengan kegunaan SIKD. Hasil penelitian ini mendukung penelitiannya Lina (2005), yang menyatakan konflik kognitif tidak berhubungan positif dengan kegunaan SAKD. Tapi temuan penelitian ini tidak mendukung penelitian Chenhall (2004), bahwa pelatihan berhubungan dengan kegunaan $A B C M$.

Pengujian hipotesis 5 tidak mampu mendukung dugaan bahwa konflik afektif berhubungan negatif dengan kegunaan SIKD. Konflik afektif tidak berhubungan dengan kegunaan SIKD. Hasil penelitian ini mendukung penelitiannya Chenhall (2004), tapi tidak mendukung dengan penelitiannya Lina (2005) yang menyatakan konflik afektif berhubungan negatif dengan kegunaan SAKD pada skala $10 \%$.

Baik konflik kognitif dan konflik afektif tidak berhubungan dengan kegunaan SIKD. Hal ini menunjukkan bahwa konflik baik itu konflik kognitif maupun konflik afektif merupakan sesuatu yang harus dihindari, apabila terpaksa terdapat konflik diusahakan tidak terbuka dan tidak secara langsung.

\section{Hubungan antara Kegunaan SIKD dengan Cost Consciousness}

Pengujian hipotesis 6 mampu mendukung dugaan bahwa kegunaan SIKD berhubungan positif dengan cost consciousness. Penelitian ini konsisten dengan Chenhall (2004), bahwa kegunaan $A B C M$ untuk perencanaan produk berhubungan dengan keberhasilan finansial. Hal ini mendukung penelitian Abernethy \& Vagonani (2004) yang menyatakan Terdapat hubungan antara peran SIA dengan cost consciousness.

Hasil penelitian ini juga mendukung penelitian Chairina (2006), bahwa pengendalian keputusan dan manajemen keputusan berhubungan dengan cost consciousness. Cost Consciousness merupakan kondisi dimana manajer sangat menyadari tentang arti penting biaya dan waktu yang dibutuhkan dalam setiap pengambilan keputusan. Cost Consciousness merupakan salah satu budaya yang harus dikembangkan dalam pemerintah daerah. Budaya tersebut hanya bisa dicapai dengan proses pembelajaran terus menerus dan menjadikan Cost Consciousness sebagai salah satu strategi bersaing (Chairina, 2006).

Cost Consciousness akan efektif bila diikuti dengan perubahan perilaku aparat pemerintah daerah. Inti dari Cost Consciousness adalah bagaimana kepala daerah dan pimpinan SKPD menaruh perhatian secara serius terhadap konsekwensi cost yang timbul bila sebuah keputusan telah diambil dan ditetapkan oleh kepala daerah dan pimpinan SKPD tersebut (Muchamad, 2006). Oleh karena itu melalui implementasi SIKD yang baik, diharapkan bisa mengembangkan perilaku Cost Consciousness. SIKD dapat memberikan informasi yang lebih baik untuk pengambilan keputusan strategis khususnya berkaitan dengan transparasi dan akuntabilitas di sektor publik. Keberadaan SIKD bisa dijadikan sebagai alat kontrol untuk mendesain aparat pemerintah daerah berperilaku Cost Consciousness. 


\section{KESIMPULAN DAN SARAN}

\section{Kesimpulan}

Faktor-faktor dalam implementasi SIKD adalah dukungan atasan, kejelasan tujuan, dan pelatihan. Dari ketiga faktor implementasi tersebut, hanya pelatihan yang berhubungan positif dengan konflik kognitif. Pelatihan juga berhubungan negatif dengan konflik afektif. Sedangkan dukungan atasan dan kejelasan tujuan tidak berhubungan dengan konflik kognitif maupun konflik afektif. Dukungan atasan merupakan dukungan dari pemerintah daerah yang berkaitan dengan persediaan sumber daya yang dibutuhkan untuk implementasi SIKD dan hubungannya dengan kemajuan dan efisiensi. Tampaknya sumber daya yang disediakan untuk implementsai sistem baru (SIKD) belum memiliki peranan dalam mendukung implementsai SIKD dan kurang potensial mempengaruhi munculnya konflik. Faktor kejelasan tujuan belum mendorong memunculkan konflik kognitif dimana manajer kemungkinan belum memiliki kemampuan dan pengetahuan akan operasional aplikasi SIKD dan belum terlibat dalam suatu interaksi yang memfokuskan pada tugas untuk mengimplementasikan SIKD secara efektif. Pelatihan memberikan peranan penting dalam meyakinkan bahwa individu sudah memiliki ketrampilan dan rasa percaya diri dalam perdebatan yang mempermasalahkan implementasi SIKD.

Faktor kejelasan tujuan berhubungan positif dengan kegunaan SIKD, sedangkan dukungan atasan dan pelatihan tidak berhubungan dengan kegunaan SIKD. Faktor implementasi SIKD kejelasan tujuan memiliki peranan penting sehingga bermanfaat untuk transparansi dan akuntabilitas di sektor publik. Sedangkan sumber daya yang dibutuhkan untuk implementasi SIKD belum memiliki peranan terhadap transparansi dan akuntabilitas di sektor publik. Kemungkinan pelatihan hanya diperuntukkan pejabat bagian atas sehingga keikutsertaan responden dalam pelatihan kurang.

Baik konflik kognitif dan konflik afektif tidak berhubungan dengan kegunaan SIKD. Hal ini menunjukkan bahwa konflik baik itu konflik kognitif maupun konflik afektif merupakan sesuatu yang harus dihindari, apabila terpaksa terdapat konflik diusahakan tidak terbuka dan tidak secara langsung.

Kegunaan SIKD berhubungan positif dengan cost consciousness. Cost Consciousness merupakan kondisi dimana manajer sangat menyadari tentang arti penting biaya dan waktu yang dibutuhkan dalam setiap pengambilan keputusan. Cost Consciousness akan efektif bila diikuti dengan perubahan perilaku aparat pemerintah daerah. Oleh karena itu melalui implementasi SIKD yang baik, diharapkan bisa mengembangkan perilaku Cost Consciousness. SIKD dapat memberikan informasi yang lebih baik untuk pengambilan keputusan strategis khususnya berkaitan dengan transparasi dan akuntabilitas di sektor publik. Keberadaan SIKD bisa dijadikan sebagai alat kontrol untuk mendesain aparat pemerintah daerah berperilaku Cost Consciousness.

\section{Saran}

Penelitian ini mempunyai implikasi yang luas di masa yang akan datang, khususnya untuk penelitian yang berkaitan dengan hubungan faktorfaktor implementasi dalam inovasi sistem. Model penelitian merupakan pengembangan dari penelitian sebelumnya oleh Chenhall (2004) sehingga penelitian ini perlu ditindaklanjuti dengan diteliti kembali apakah implementasi sistem dipengaruhi oleh faktor-faktor implementasi lain dan perlu dikembangkan untuk meneliti faktor-faktor teknis. Hal ini disarankan karena faktor-faktor yang menentukan implementasi sistem bukan hanya dari faktor perilaku tapi juga teknis yang juga sangat berpengaruh. Penelitian ini juga menyarankan 
untuk penelitian selanjutnya dengan memperluas obyek penelitian dengan memilih responden yang mempunyai jabatan yang setingkat supaya hasilnya dapat digeneralisaikan.

Hasil penelitian ini diharapkan dapat memberikan konstribusi sebagai bahan pertimbangan implikasi SIKD di Indonesia terutama yang berhubungan dengan faktor-faktor implementasi dari pengguna sistem. Penelitian ini juga diharapkan dapat memberikan suatu gambaran kepada pemda bahwa kesuksesan implikasi sistem tidak hanya ditentukan oleh faktor teknis dan dana, namun pengguna sistem juga perlu diperhatikan.

\section{DAFTAR PUSTAKA}

Abdul Halim (2002), Akuntansi Keuangan Daerah, Edisi Pertama, Salemba Empat, Jakarta.

Abernethy, M. A., and A. M. Lillis (2001), Interdependencies in Organization Design: A Test in Hospitals, Journal of Management Accounting Research, Vol. 13.

and Emidia Vagnoni (2004). Power, Organization Design and Managerial Behavior. Organizations. Accounting, Organization and Society, 29, 207-225.

..........., and Jan Bouwens (2005), Determinants of accounting innovation, ABACUS, Vol. 1.

Ahmad Suhaili (2004), Analisis Faktor-Faktor Yang Mempengaruhi Pemanfaatan Tehnologi Informasi dan Pengaruhnya Terhadap Kinerja Manajerial Pada Perusahaan Manufaktur di Kalimantan Selatan, Tesis Program Pasca Sarjana Magister Sains Universitas Diponegoro (tidak dipublikasikan).
Anderson, S.W, \& Young, S.M, (1999), The Impact of contextual and Process Factors on The Evaluation of Activity-Based Costing Systems, Accounting, Organization and Society, 24, 525-559.

Augusty Ferdinan (2002), Structure Equation Modeling dalam Penelitian Manajemen, Badan Penerbit universitas Diponegoro.

Cavalluzzo, K. S., and C. D. Ittner (2204), Implementing Performance Measurement

Innovations: Evidence From Government, Accounting, Organizations and Society, Vol. 29, Nos 3-4.

Chairina (2006), Pengaruh Kekuasaan, desain Organisasi dan Perilaku Manajer Terhadap Cost Conciousness (Studi Pada Perusahaan Daerah Se-Propinsi Kalimantan Selatan), Tesis Program Pasca Sarjana Magister Sains Universitas Diponegoro (tidak dipublikasikan).

Chenhall, R.H, (2004), The Role of Cognitive and Affective Conflict in Early Implementation of Activity-Based Cost Management, behavioral Research in Accounting, Vol. $16,19-44$.

Cooper,R., R.S.Kaplan.L.S. Maisel.E.Morrisey adan R.M. Ochm (1992), Impelementing Activity Based Costing, Institute Of Management Accountant.

Foster, G. \& Swenson, D.W, (1997), Measureng The Success of Activity-Based Cost Management and Its determinants, Journal of Management Accounting Research. Vol. 9.

Hair, J.R, Anderson, R.E. Tarham, R.L. Beack, W.C. (1998). Multivariate data Analysis, Fitth Edition, Prentice Hall International Inc.

Imam Ghozali (2004), Model Persamaan Struktural : Konsep dan Aplikasi dengan Program AMOS Ver. 5.0. Badan Penerbit Universitas Diponegoro. 
Indra Bastian, Akuntansi Sektor Publik di Indonesia. BPFE Yogyakarta, 2002

Krumwiede,K.R., (1998).The Implementation Stages of Activity Based Costing and The Impact of Contextual and Organizational Factor. Journal of Management Accounting Research. Vol.10.

Lina Latifah (2006), Pengaruh Faktor Organisasional Terhadap Kegunaan SAKD Dengan Konflik Sebagai Variabel Mediasi (Studi Empiris Pada Pemerintah Kabupaten dan Kota di Jawa Tengah dan Daerah Istimewa Yogyakarta), Tesis Program Pasca Sarjana Magister Sains Universitas Diponegoro (tidak dipublikasikan).

Mardiasmo (2002), Akuntansi Sektor Publik, Andi Yogyakarta.

McGowan,A.S,. and T.P.Klammer (1997), Satisfaction with Activity Based Cost Management Implementation, Journal of Management Accounting Research, Vol.9.

Miah, N.Z and Mia L (1996), Desentralitation, Accounting control system and Performance of Government Organization : A new Zaeland Empirical Study', Financial Accountability and management, August.

Muchamad Syafrudin(2005), Pengaruh Moderasi FaktorInovasipadaHubungan Partisipasi Anggaran, Struktur Terdesentralisasi dan Kinerja Manajemen, Studi di Organisasi Pemerintah Daerah, Jurnal Akuntansi Dan Keuangan Sektor Publik, Volume 06. No. 02. Agustus.

(2006), Dampak Kekuasaan pada Penggunaan SIA untuk Kontrol Keputusan dan Manajemen Keputusan dan Perilaku Manajerial : Studi pada Organisasi Pemerintah Daerah, Working Paper.

Nur Indriantoro dan Bambang Supomo (2002), Metodelogi Penelitian Bisnis, BPFE Yogyakarta.
Republik Indonesia, Undang-Undang Republik Indonesia, No. 25 Tahun 2004 tentang Sistem Perancangan Pembangunan Nasional. Departemen Dalam Negeri Republik Indonesia. , Undang-Undang Republik Indonesia, No. 32 Tahun 2004 tentang Pemerintah daerah. Departemen Dalam Negeri Republik Indonesia. , Undang-Undang Republik Indonesia, No. 33 Tahun 2004 tentang Perimbangan Keuangan antara Pemerintah Pusat dan Pemerintah daerah. Departemen Dalam Negeri Republik Indonesia , Peraturan Pemerintah Republik Indonesia, No. 24 Tahun 2005 tentang Standar Akuntansi Pemerintahan. Departemen Dalam Negeri Republik Indonesia.

Republik Indonesia No. 55 Tahun 2005 tentang Dana Perimbangan antara Pemerintah Pusat dan Pemerintah daerah. Departemen Hukum dan Hak Asasi Manusia Republik Indonesia.

Peraturan Pemerintah

Republik Indonesia No. 56 Tahun 2005 tentang Sistem Informasi Keuangan Daerah. Departemen Hukum dan Hak Asasi Manusia Republik Indonesia.

Peraturan Pemerintah

Republik Indonesia No. 58 Tahun 2005 tentang Pengelolaan Keuangan Daerah. Departemen Hukum dan Hak Asasi Manusia Republik Indonesia. , Kepmendagri No.900-009 Tahun 1981 tentang Manual Adminitrasi Keuangan daerah (MAKUDA). Departemen Dalam Negeri Republik Indonesia. 
, Kepmendagri No. 29 Ta-

hun 2002 tentang Pedoman Pengurusan, Pertanggungjawaban dan Pengawasan Keuangan Daerah Serta Tata Cara Penyusunan Anggaran Pendapatan dan Belanja Daerah, Pelaksanaan Tata Usaha Keuangan Daerah dan Penyusunan Perhitungan Anggaran Pendapatan dan Belanja Daerah. Departemen Dalam Negeri Republik Indonesia

Robbins, Stephen P (1989), Organization Behavior Concept, Contraversies and Application. Eighth Edition, Pretice Hall, Inc.

Robinson (2006), Pengaruh Kualitas Anggaran Terhadap Efektivitas Pengawasan Anggaran : Pengetahuan Anggaran Sebagai Variabel Moderating (Studi Empiris Pada DPRD Kabupaten dan Kota Se-Propinsi Bengkulu), Tesis Program Pasca Sarjana Magister Sains Universitas Diponegoro (tidak dipublikasikan).

Syaikhul Fatah (2006), Pengaruh Budaya Etis Organisasi dan Orientasi Etika Terhadap Sensitivitas Etika (Studi Empiris Tentang Pemeriksaan Internal di Bawasda Pemda Papua), Tesis Program Pasca Sarjana Magister Sains Universitas Diponegoro (tidak dipublikasikan).

Shields, M. D. (1995), An Empirical Analysis of Firms' Implementation Experiences With Activity-Based Costing, Journal of Management Accounting Research, Vol.7.

Uma Sekaran (1992), Research Methods For Business : A Skill Budding Approach, Second Edition, john Willy \& Sons, Anc. 